\section{Selivorstov V., Dotsenko $\mathbf{N}$., Dotsenko $Y$., Dotsenko V.}

\title{
DETERMINATION OF THE ESSENTIAL EFFECT OF MODIFICATION IN THE COMPOSITION OF THE COMBINED VIBRATION TREATMENT TECHNOLOGY ON THE MECHANICAL PROPERTIES OF AK7 ALLOY
}

Об’єктом дослідження є сплав АК7, що піддається комплексній дї̈ вібрацї та модифікування в процесі виробництва циліндричних заготовок способом лиття в кокіль. Одним з найбільш проблемних місць є визначення раціональних режимів впливу технологічних факторів на сплав, що забезпечують задоволення заданого рівня властивостей за умов їх конкуруючої природи.

В ході дослідження використовувалися методи регресійного аналізу та визначалися за перспективні методи дисперсійного аналізу для підвищення точності висновків. Зокрема, наведено результати регресійного аналізу даних експериментально-промислових досліджень технології віброобробки з частотою 100-150 Ги, з додатковим вводом у розплав ультрадисперсного модифікатору. Отримано результати, що стосуються підтвердження гіпотези щодо значущості впливу модифікатора на підвищення механічних властивостей сплаву: $Н B, \sigma_{0.2}, \sigma_{s}, \delta_{s}, \psi$. Це важливо, бо намагання підвищити властивості сплаву використанням комбінованих технологічних рішень незмінно викликає витрати енергї та матеріальних ресурсів. Завдяки цьому забезпечується можливість енерго- та ресурсозаощаджень в технологічному процесі. Отримані результати показали, що використання модифікування як додаткової складової тех-

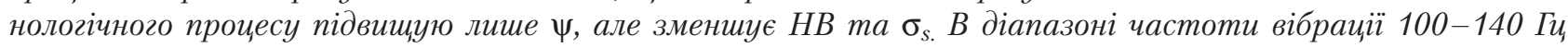
модифікування позитивно впливає на $\sigma_{0.2}$, підвищення ж частоти вище иієї величини призводить до погіршення результату. Зворотній ефект спостерігається відносно $\delta_{s}-$ з підвищенням частоти вібраціі понад 140 Ги, модифікування підвищує ию характиристику сплаву, в діапазоні 100-140 Ги, введення модифікатора можна вважати не обгрунтованим. Таким чином, встановлено, що модифікування неоднозначно впливає на властивості сплаву, тому для вибора раціонального технологічного режиму потрібне вирішення компромісної задачі. Це пов'язано з виявленим фактом конкуруючих властивостей. Запропоновано для уточнення отриманих результатів використати методи дисперсійного аналізу.

Ключові слова: технологї̈ віброобробки, вплив модифікування, сплав АК7, регресійний аналіз, дисперсійний аналіз.

\section{Introduction}

External effects on alloys are based on the use of different physical principles, for example:

- complex treatment of liquid silumin in a magnetodynamic unit (MDU) [1], which allows to eliminate liquation, grind the structural components of pre- and hypereutectic silumin, increase the relative elongation of the alloys;

- treatment by increasing pressure and modifying [2], providing a complex effect on the micro- and macrostructure of the alloy;

- complex treatment by vibration and directional crystallization [3], which allows to increase the mechanical properties due to the grinding of grain.

The possibilities of regulating the structure formation processes during the vibration process are noted in $[4,5]$. It is shown that when exposed to a metal with an electric vibrator, the economic aspects of the implementation of such technological solutions should be taken into account [6]. In [7, 8], variants of technological implementations of the vibration process for pouring traction drive electric motors into the molds of rotors are described. It is noted that the use of selected modes in the practice of casting rotors minimizes the probability of formation of internal porosity, thus providing the best traction characteristics. Therefore, it is relevant to apply an integrated approach to the impact on the liquid metal. Thus, the object of research is AK7 alloy, which is subjected to the complex effect of vibration and modification during the production of cylindrical billets by means of casting in a casting mold. The aim of research is mathematically confirmation or denies the effect of modifying, as part of the combined treatment of a melt by vibration, on the mechanical properties of the alloy.

\section{Methods of research}

Experimental industrial data obtained under the conditions of the foundry shop of Dnipropetrovsk Aggregate Plant OJSC (Ukraine) [9] were taken as the basis for the analysis. Melting of the AK7 alloy was performed in a CAT-04 furnace. Filling was carried out in a steel turnout casting mold with an average diameter of $60 \mathrm{~mm}$ with 
a wall thickness of $5 \mathrm{~mm}$ and a working cavity height of $150 \mathrm{~mm}$. Previously, the working cavity of the casting mold was heated to $380-400{ }^{\circ} \mathrm{C}$ and covered with paint based on disten sillimanite. Heated casting mold with a protective coating was installed and fixed on the vibration installation, providing after pouring the mode of vibration exposure with amplitude of $0.7 \mathrm{~mm}$ at a frequency of $100 \mathrm{~Hz}, 150 \mathrm{~Hz}, 200 \mathrm{~Hz}$. The melt was poured into the casting mold at a temperature of $720 \pm 5{ }^{\circ} \mathrm{C}$.

In the process of vibration at these frequencies, two series of experiments were carried out:

Series 1: Filling of the unmodified and modified by the preparation «Typhoon-Z» $(0.1$ wt. \%).

Series 2: Filling of unmodified and modified alloy in the casting mold without vibration.

After cooling the poured samples, the mechanical properties and density of the alloy were measured. The experimental method is described in detail in [9].

On the basis of the obtained data, a table of results was formed, on the basis of which a regression analysis was carried out using the Excel spreadsheet environment. The task was in determination of the effect of modifying on the properties of the alloy as an additional factor of influence, together with vibration.

\section{Research results and discussion}

Fig. 1-5 show the results of the regression analysis aimed at identifying the influence of the vibration frequency on the properties of the alloy for each process mode - vibration and vibration+modification.

Fig. 1-5 show that the answer to the question of the significant effect of modification as an additional factor is ambiguous. So, from Fig. 1 it is shown that the modification reduces the hardness of the alloy in comparison with the vibration treatment. The same conclusion can be drawn with respect to $\sigma_{s}$ (Fig. 3).

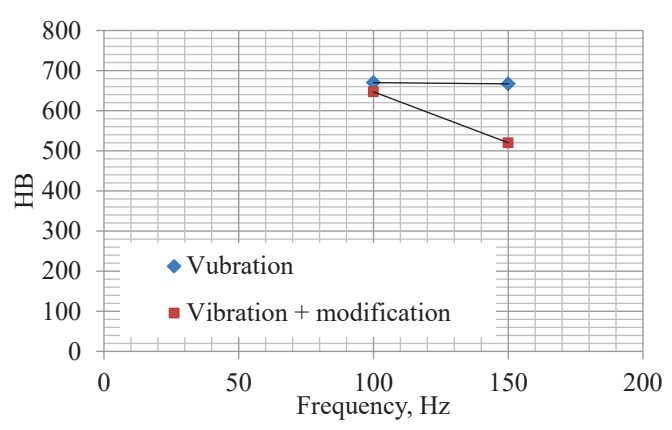

Fig. 1. $H B=H B(f)$ dependence

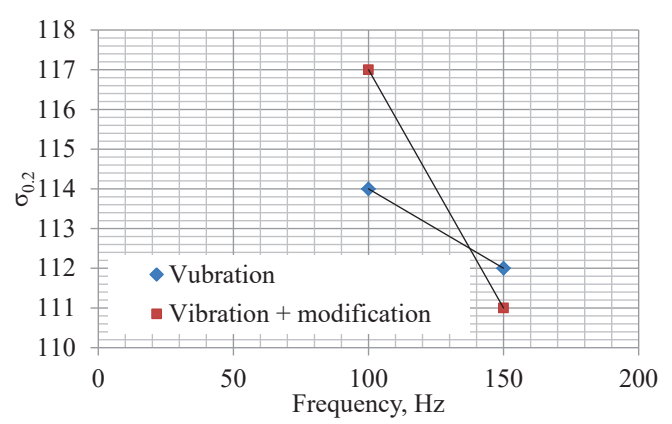

Fig. 2. $\sigma_{0.2}=\sigma_{0.2}(f)$ dependence

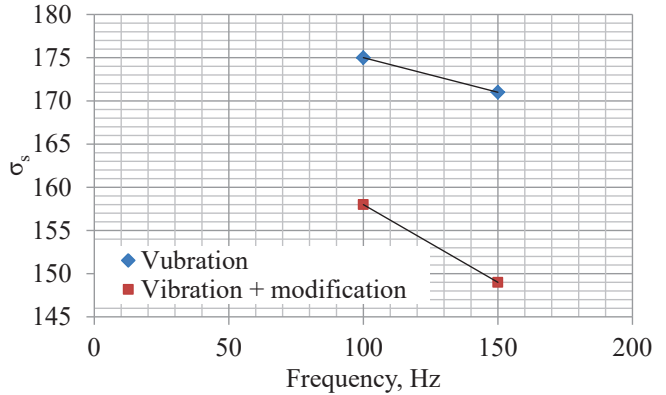

Fig. 3. $\sigma_{s}=\sigma_{s}(f)$ dependence

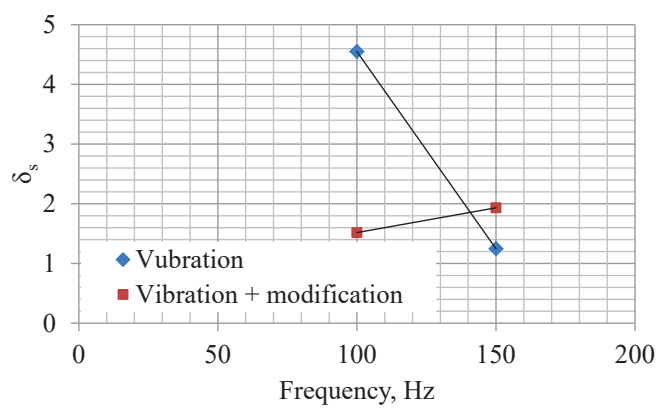

Fig. 4. $\delta_{s}=\delta_{s}(f)$ dependence

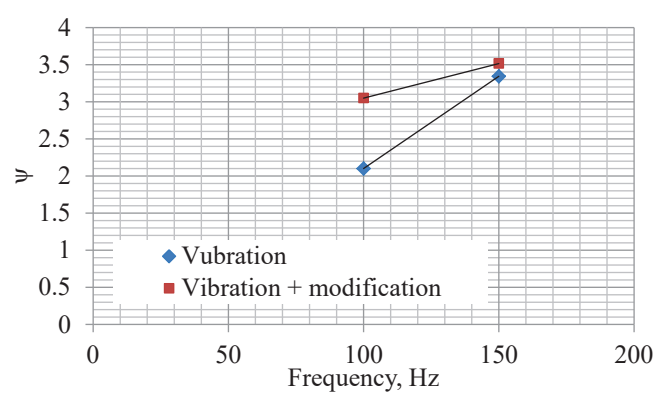

Fig. 5. $\psi=\psi(f)$ dependence

However, the modification increases $\sigma_{0.2}$, but only up to a frequency of $140 \mathrm{~Hz}$, the frequency excess leads to worse results compared to the usual vibration treatment. Modification has a positive effect on $\sigma_{s}$ only when the frequency exceeds $140 \mathrm{~Hz}$ (Fig. 4). In relation to $\psi$, it can be said that in the entire frequency range of vibration, the action of the modifier enhances this characteristic of the alloy (Fig. 5).

It should be noted that the graphs (Fig. 1-5) were obtained for the average values of the properties of the alloy (mathematical expectations). Mathematical expectations were calculated as the average of parallel measurements $(n=2$ or $n=3)$. The difference in the sample size and the characteristics of the object of research leads to the fact that the variance can't be determined with sufficient accuracy. It is possible to talk about the assessment of dispersions, which should be considered when comparing the two technological modes - treatment of the alloy with pure vibration and the combined treatment of vibration + modification. Therefore, the need for the use of an analysis of variance can be considered a prospect for the development of this study [10]. The well-known results of work [11], devoted to the use of an analysis of variance to assess the significance of the effect of modifying on the quality of an alloy, allow to consider it reasonable for the problem under consideration. The task in this case is to determine whether the effect of modification on the increase of mechanical properties and the density of the alloy in the process of vibration treatment 
is significant. The procedure algorithm is as follows. The group average contents of the $y^{(i)}$ values for the alloy not treated with the modifier $\left(y^{(i 0)}\right)$ and treated with the modifier $\left(y^{(i 1)}\right)$ are calculated:

$$
\begin{aligned}
& \overline{y_{j, \mathrm{gr}}^{(i 0)}}=\frac{1}{n} \sum_{i=1}^{n} y_{j, i}^{(i 0),} \\
& \overline{y_{j, \mathrm{gr}}^{(i 1)}}=\frac{1}{n} \sum_{i=1}^{n} y_{j, i}^{(i 1)},
\end{aligned}
$$

where $\overline{y_{j, \mathrm{gr}}^{(i 0)}}, \overline{y_{j, \mathrm{gr}}^{(i 1)}}-$ the average group values of the properties of the unmodified and modified alloy, respectively; $n$ - the number of parallel measurements of the properties of the alloy; $y_{j, i}^{(i 0)}, y_{j, i}^{(i 1)}$ - values of properties in each of the parallel measurements of unmodified and modified alloy, respectively.

The residual dispersion is calculated:

$$
S_{r}^{2}=\frac{1}{(n k-k)} \sum_{j=1}^{k} \sum_{i=1}^{n}\left(y_{j, i}^{(i)}-\overline{y^{(i)}}\right)^{2},
$$

where $k$ - the number of levels; $k=2$ (the first level is an unmodified alloy, the second level is a modified alloy); $y_{j, i}^{(i)}-$ the value of the properties of the alloy in each experiment; $\overline{y^{(i)}}$ - the total average value of the $i$-th alloy property, determined by the formula:

$$
\overline{y^{(i)}}=\frac{1}{k}\left(\sum_{j=1}^{k} \overline{y_{j, \mathrm{gr}}^{(i)}}\right) .
$$

The factor variance is calculated:

$$
s_{f}^{2}=\frac{1}{k} \sum_{j=1}^{k}\left(\overline{y_{j, g r}^{(i)}}-\overline{y^{(i)}}\right)^{2},
$$

where $\overline{y_{j, g r}^{(i)}}$ - the average group values of the properties of the alloy, defined for unmodified and modified alloys by the formulas (1), (2), respectively.

When the condition is met:

$$
F=\frac{s_{f}^{2}}{s_{r}^{2}}>F_{c r},
$$

the effect of the modifier on the $i$-th alloy property should be considered significant. Otherwise, the influence of the factor is considered insignificant. In this case, using the Student's $t$-criterion, the level from which its influence is manifested is determined. However, this requires additional experimental studies with different amounts of the introduced modifier.

\section{Conclusions}

It is shown that the use of an ultradisperse modifier as an additional technological step for vibration treatment of the AK7 system alloy by means of a casting in a metal mold increases the value of $\psi$ over the entire range of vibration frequencies studied $(100-150 \mathrm{~Hz})$, but reduces the $\mathrm{HB}$ and $\sigma_{s}$. In the frequency range of $100-140 \mathrm{~Hz}$, modifying increases $\sigma_{0.2}$, however, when the frequency exceeds $140 \mathrm{~Hz}$, the positive effect of the modifier ceases and its use becomes unjustified in relation to this alloy characteristic. The opposite effect has been established with respect to the effect of the modifier on $\sigma_{s}-$ the use of the modifier is justified only in the frequency range of $140-150 \mathrm{~Hz}$. To refine the obtained results, it is necessary to carry out an analysis of variance, which will require additional experiments.

The obtained results suggest that competing criteria in the properties of the alloy and the need for a compromise solution to the problem of choosing rational technological modes of AK7 alloys processing in the manufacture of cylindrical blanks by casting in a casting mold.

\section{References}

1. Kompleksnaia obrabotka splavov sistemy Al-Si v magnitodinamicheskoi ustanovke s posleduyuschei intensivnoi plasticheskoi deformatsiei: vliianie na svoistva i strukturu / Skorobagat'ko Yu. P., Slazhnev N. A., Berezina A. L., Monastyrskaia T. A., Davidenko A. A., Spuskanyuk V. Z. // Protsessy lit'ia. 2010. Issue 5. P. 83-88.

2. Dotsenko Yu. V., Seliverstov V. Yu. Osobennosti zatverdevaniia otlivok iz alyuminievyh splavov pri narastayuschem davlenii i modifitsirovanii // Eastern-European Journal of Enterprise Technologies. 2012. Vol. 1, Issue 5 (55). P. 18-22.

3. Effect of Lateral Vibrations during Directional solidification on Mechanical Properties of Al-18\%wt Si Alloys / Ramesh Babu N., Ramesh M., Kiran Aithal S., Kotresh K. // Materials Today: Proceedings. 2018. Vol. 5, Issue 2. P. 6954-6962. doi: http://doi.org/10.1016/j.matpr.2017.11.358

4. Dommaschk C. Beitrag zur Gefügebeeinflussung erstarrender Metallschmelzen durch Vibration. TU Bergakademie Freiberg, 2003. 134 p.

5. Buxmann K. Auswirkung von Schock, Vibration und Strömung auf die Erstarrung von Metallen // Zeitschrift Metallkunde. 1972. Vol. 63, Issue 9. P. 516-521.

6. Kotova Yu. V., Kotov R. N., Bast Yu. Vnedrenie i analiz vibratsii pri neprereryvnom lit'e zagotovok iz dragotsennyh metallov // Vestnik Permskogo gosudarstvennogo tekhnicheskogo universiteta. Mashinostroenie, materialovedenie. 2010. Vol. 12, Issue 4. P. 80-84.

7. Akimov O. V., Chibichik O. A., Red'kina A. V. Sovershenstvovanie tekhnologicheskih protsessov izgotovleniia lityh detalei rotorov dlia povysheniia ekspluatatsionnyh harakteristik tiagovogo elektroprivoda // Problemy mashinostroeniia. 2014. Issue 16 (5). P. 7-12.

8. Metodologiia konstruktorsko-tekhnologicheskogo proektirovaniia i izgotovleniia korotkozamknutogo litogo rotora dlia asinhronnyh elektrodvigatelei / Chibichik O. A., Martynenko V. F., Akimov O. V., Shishko A. E. // Metall i lit'e Ukrainy. 2011. Issue 2 (213). P. 30-34.

9. Selyverstov V. Yu., Dotsenko Yu. V., Dotsenko N. V. Kompleksnyi vplyv modyfikuvannia ultradyspersnym preparatom ta vibratsiieiu na vlastyvosti metalu vylyvkiv iz splavu systemy $\mathrm{Al}-\mathrm{Si}$ : proceeding // Spetsialna metalurhiia: vchora, sohodni, zavtra. Kyiv: KPI im. Ihoria Sikorskoho, 2018. P. 336-345.

10. Charykov A. K. Matematicheskaia obrabotka rezul'tatov himicheskogo analiza: textbook. Leningrad: Himiia, 1984. 168 p.

11. Demin D. A., Pelikh V. F., Ponomarenko O. I. Complex alloying of grey cast iron // Litejnoe Proizvodstvo. 1998. Vol. 10. P. 18-19.

12. Demin D. A. Change in cast iron's chemical composition in inoculation with a Si-V-Mn master alloy // Litejnoe Proizvodstvo. 1998. Vol. 6. P. 35

Selivorstov Vadim, Doctor of Technical Sciences, Professor, Department of Foundry Production, National Metallurgical Academy of Ukraine, Dnipro, Ukraine, e-mail: seliverstovoy@gmail.com, ORCID: http://orcid.org/0000-0002-1916-625X

Dotsenko Nataliia, Postgraduate Student, Department of Foundry Production, National Metallurgical Academy of Ukraine, Dnipro, Ukraine, e-mail: yvd160574@gmail.com, ORCID: http://orcid.org/ 0000-0003-3570-5900

Dotsenko Yuri, PhD, Associate Professor, Department of Foundry Production, National Metallurgical Academy of Ukraine, Dnipro, Ukraine, e-mail: yvd160574@gmail.com, ORCID: http://orcid.org/ 0000-0002-7734-7884

Dotsenko Vadym, PhD, Associate Professor, Department of Technology and Management of Foundry Processes, Odessa National Polytechnic University, Ukraine, ORCID: http://orcid.org/00000002-8400-0491 